\title{
For the Kids: A Place for Equity in Kansas School Finance Litigation
}

\author{
Alexandra Rose
}

\section{INTRODUCTION}

"Education is the most powerful weapon which you can use to change the world"

\section{- Nelson Mandela}

Education. Say the word and a hundred different things come to mind. Bad teachers, good teachers, old textbooks, science experiments, politicians fighting, kids at recess, money. There are many different views on what makes a quality education, but most everyone agrees with Mandela - education can be the silver bullet. Education can propel an immigrant who barely knows English to the chairperson position in a Fortune 500 company. ${ }^{1} \quad$ It can reconcile groups of people that have clashed for decades. ${ }^{2}$ And education can show children a world they may not dare dream of - a world without limitations.

\footnotetext{
* J.D. Candidate May 2016, University of Kansas School of Law; B.A. Political Science 2013, University of Kansas. I would like to thank Professor Richard Levy for his invaluable insight and advice, both as to substance and style. I would also like to thank my editor, Paul Mose. Without Paul I would not have found this topic or the passion it instilled in me. And of course, I want to also recognize the support and love of my family, biologically and sentimentally related alike-I am who I am because of all of you, for better or worse. But no dedication would be complete without thanking those who have enabled me to get where I am today: Sisters Corita, Marjorie, and Angela Rose, for loving each and every one of us at Assumption; Mrs. Figgs, for always keeping a book in my hand; Darrel Heurter, for recognizing something in me that I have yet to discover; Cindy Burgett, for teaching me invaluable advocacy skills; Heather Huscher, for sharing her story and pushing me forward; Patricia Brockman, for teaching me how to write under fire; Dr. Kala Mays Stroup, for forcing me to become a better woman, student, professional, and mentor than I ever knew I could be; the women of Alpha Delta Pi, for helping me find my confidence again; and last but not least Professor Michael Davis, for making me write on to law review in the first place.

1. Italian immigrant Paul Oreffice served as CEO of The Dow Chemical Company for nearly 40 years. Mr. Oreffice came to the United States to get an education, but when he arrived he knew only about fifty words of English. His autobiography hails Mr. Oreffice's story as a modern-day Horatio Alger story, and it very well may be. See generally PAUl OREFFICE, ONLY IN AMERICA: FROM IMMIGRANT TO CEO (2006).

2. See generally Education and Training InSPectorate, A Final EVAluation of the INTERNATIONAL FUND FOR IRELAND's SHARING IN EDUCATION PROGRAMME (2013), http://www.e
} 
Kansans have been debating the best way to educate our children since the state was a territory. ${ }^{3}$ The nation has been debating it since long before that. ${ }^{4}$ Today, the debate is about money-who gets it and how much? Over the past several decades the debate about how best to fund education has taken center stage, both in Kansas and across the nation. ${ }^{5}$ School administrators, parents, and education advocates grew tired of lobbying state legislators for more funding and went to the courts - ushering in decades of school-finance litigation. ${ }^{6}$

Courts across the nation have heard so many variations on the school funding theme that commentators are able to divide these suits into three waves: national equity, state-based equity, and adequacy. ${ }^{7}$ The first wave quickly fizzled when the Supreme Court declined to deem education a fundamental right under the Federal Constitution. ${ }^{8}$ Thwarted but not discouraged, advocates brought litigation in state courts challenging the equity of school-finance systems. ${ }^{9}$ Although advocates saw some success in these state-based equity cases, they did not achieve the plaintiffs' goal-more funding. ${ }^{10}$ Thus entered the third and current wave: adequacy litigation.

Adequacy litigation aims to circumvent legislative lobbying and win increased school funding through court orders. ${ }^{11}$ State courts disagree about the judiciary's role in adequacy focused school-finance litigation. ${ }^{12}$ Where equity litigation strictly asked the judiciary to determine whether

tini.gov.uk/international-fund-for-irelands-sharing-in-education-programme/a-final-evaluation-ofthe-international-fund-for-irelands-sharing-in-education-programme.pdf (describing the success of youth educational programs in reconciling conflict between Protestants and Catholics in Northern Ireland).

3. Infra Part II.A.

4. See Race Forward, Historical Timeline of Public Education in the U.S., RACE FORWARD, https://www.raceforward.org/research/reports/historical-timeline-public-education-us (last visited May 24, 2015) (“1779: Thomas Jefferson proposes a two-track educational system, with different tracks in his words for 'the laboring and the learned.' Scholarship would allow a very few of the laboring class to advance, Jefferson says, by 'raking a few geniuses from the rubbish."').

5. See infra Part II.B-C.

6. See infra Part II.B.

7. Id.

8. Id.

9. Id.

10. Id.

11. See infra Parts II.B, III.A.

12. Compare Neb. Coal. for Educ. Equity \& Adequacy v. Heineman, 731 N.W.2d 164, 183 (Neb. 2007) (finding that a lack of constitutional, qualitative standards weighs heavily against justiciability in school-finance litigation), with Gannon v. Kansas, 319 P.3d 1196, 1208-31 (Kan. 2014) (finding adequacy justiciable by denying the State's attempt to characterize the issue as a political question). 
state education funds were distributed equitably among school districts, adequacy litigation asks the court to determine how much money is required to fund an adequate education. ${ }^{13}$ Courts hearing adequacy litigation usually must first decide a separation of powers problem concerning the proper role of the legislature and judiciary in school funding. ${ }^{14}$ Adequacy plaintiffs have had great success in winning cases, but not resolving them ${ }^{15}$ - an adequacy case has been pending in one state court for more than fifteen years. ${ }^{16}$

Like most states, Kansas included education in its constitution. ${ }^{17}$ Article VI of the Kansas Constitution requires the legislature to provide suitable funding to support free public schools. Article VI has spawned decades of school funding challenges, particularly equity and adequacy litigation - the most recent challenge coming in Gannon v. Kansas ${ }^{18}$ in March of 2014. ${ }^{19}$ Gannon was the first time the Kansas Supreme Court addressed whether adequacy challenges violate separation of powers principles. ${ }^{20}$ The court found adequacy justiciable and imported a vague seven-part test. ${ }^{21}$ Gannon also adopted a test for determining whether state funds are equitably distributed among schools: school districts must "have reasonably equal access to substantially similar educational opportunity through similar tax effort." ${ }^{22}$ The court, however, did not explain how to apply this rule in future litigation. "Educational opportunity" itself is a phrase that lacks a definition; even the scholar who first used the phrase failed to define it. ${ }^{23}$

This Comment argues that the Kansas Supreme Court went too far and not far enough in Gannon. Adequacy is a popular trend in schoolfinance litigation and, although an adequate education is admirable and necessary, it is no place for the courts. Adequacy presents a nonjusticiable political question under Article VI of the Kansas Constitution. First, and most importantly, the decision on how best to provide funding

13. See infra Parts III.A.2, B.

14. See, e.g., Heineman, 731 N.W.2d at 179 (discussing political question and adequacy litigation); Gannon, 319 P.3d at 1216-31 (discussing political question and adequacy litigation).

15. See infra Part III.A.2.

16. Abbott v. Burke, 710 A.2d 450 (N.J. 1998).

17. KAN. CONST. art. VI.

18. 319 P.3d 1196 (Kan. 2014).

19. Infra Part II.C.

20. Gannon, 319 P.3d at 1216.

21. Id. at 1236 .

22. Id. at 1239 .

23. James S. Coleman, What is Meant by 'an Equal Educational Opportunity'?, 1 OXFORD REV. EDUC. 27, 27 (1975). 
for schools is committed to the legislature. And not only is funding committed to the legislature, the Article VI term used to support the court's decision to hear adequacy cases was "suitable"- a term too vague to provide judicially discoverable and manageable standards. The text and history of Article VI, as well as separation of powers principles, lean heavily in favor of deeming adequacy litigation a non-justiciable political question in Kansas. On the other hand, Kansas courts have a long history of hearing equity cases. Accordingly, courts and advocates should focus on Gannon's equity test. In applying Gannon's equity test, the court should focus on a formulation that increases resources to the less advantaged students and districts - a concept this Comment calls "vertical equity." Applying Gannon's equity test from a vertical equity perspective allows the court to aid the State in fulfilling its constitutional mandate to educate Kansans for a better tomorrow.

This Comment starts by illustrating the history of public-education laws and funding in Kansas. ${ }^{24}$ Part II provides a brief discussion of the evolution of school-finance litigation in Kansas and across the nation. ${ }^{25}$ Part III begins with a discussion of adequacy's non-justiciability under the Kansas Constitution and an illustration of adequacy litigation's practical problems. ${ }^{26}$ Part III then examines what equity as a general concept means and the two types of equity often discussed in schoolfunding literature. ${ }^{27}$ Finally, this Comment proposes that courts adopt a vertical equity perspective when applying Gannon's equity test in future litigation. $^{28}$

\section{BACKGROUND}

\section{A. Education in Kansas: Schools Before Statehood}

Kansas's investment in education began before the state was actually a state. ${ }^{29}$ In 1851, the Kansas Territory established the soon-to-be-state's first free public school in Council Grove. ${ }^{30}$ By the 1870 s, log-cabin schools were popping up throughout the state and by 1885 Kansas was

24. Infra Part II.A.

25. Infra Part II.B-C.

26. Infra Part III.A.

27. Infra Part III.B.

28. Infra Part III.C.

29. See Sherrill martinez \& Lue ann Snider, Kan. State Dep't of Educ., History of KANSAS EDUCATION 3 (2001).

30. Id. at 6 . 
investing in high schools. ${ }^{31}$ The young state's dedication to education went beyond simply erecting schools. From the start, Kansas was concerned with the level of education it was providing children. As early as 1873 , the state was requiring would-be teachers to pass certification exams before they would be deemed qualified to teach. ${ }^{32}$ State training schools for teachers soon followed. ${ }^{33}$

1. Funding a Quality Education in the Sunflower State

Fast forward to the 1900s and Kansas is still focused on education. The famous Brown v. Board of Education case, decided in 1954, sprang from the state's capital-Topeka. ${ }^{34}$ However, Kansans were concerned with much more than just racial equity, they were also concerned with equity of educational opportunity. Throughout the 1950s, Kansas provided reimbursements to programs aimed at educating the handicapped, and in 1969 funding for special-education programs became law. ${ }^{35}$ By the 1970s, Kansans had lobbied for a multi-track curriculum designed to aid student success by providing options for atrisk students. ${ }^{36}$ There was never a time that Kansans were not concerned with providing their children with a high quality education-it was ingrained in Kansas from the start that education is key to growing the state. ${ }^{37}$

Kansas's commitment to funding public education has been enshrined in the state's laws and constitution almost as long as it has lived in the people's hearts. In 1854, seven years before being admitted to the Union, Kansas passed its first school-funding law as part of The Organic Act. ${ }^{38}$ The Organic Act devoted tracts of state land to fund common schools. ${ }^{39}$ Five years later, the people of Kansas adopted a territorial constitution that adopted The Organic Act's school funding provision. ${ }^{40}$ In 1861 , Kansas finally became a state and its newly minted

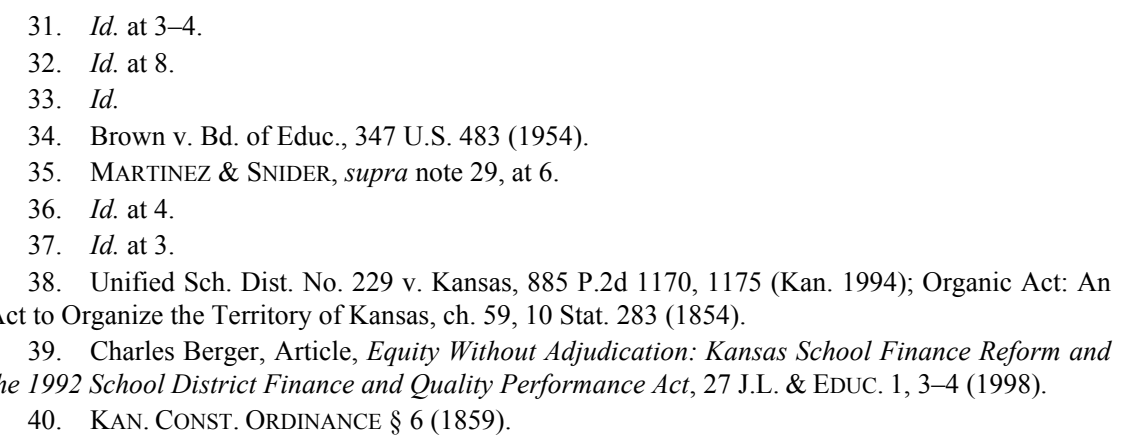


constitution included even more support for school funding than the territorial constitution and Organic Act. ${ }^{41}$ Article VI, Section Four of The Kansas Constitution of 1861 provided that "income of the State school funds shall be disbursed ... to the treasurers of the several school districts, in equitable proportion to the number of children and youth resident therein." ${ }^{42}$ Although local taxes provided a large portion of the early schools' funding, the constitution was concerned with disbursing state funds equitably and succeeded in establishing "a sort of frontier equality in [the] system."43

Adoption of Article VI was not the end of school funding efforts in Kansas. In 1911, Kansas passed a law providing supplemental funding to schools that could not afford to stay open seven months out of the year on their own. ${ }^{44}$ Some thirty years later the State's first modern school funding equalization act was passed. ${ }^{45}$ Then, in 1949, equity became a part of the school funding formula. ${ }^{46}$

\section{A Renewed Constitutional Commitment to State Funding}

Starting in the 1940s Kansas saw a boom in the number of school districts. ${ }^{47}$ This surge was not the result of organized efforts and resulted in administrative confusion and chaos. ${ }^{48}$ The state legislature soon began instituting reforms to try and organize the public-education system as well as to reduce the number of school districts. ${ }^{49}$ The legislature's unification measures were challenged in court for unconstitutionally delegating legislative power to the superintendent. ${ }^{50}$ The legislature prevailed, but the case prompted a proposed amendment of Article VI. ${ }^{51}$ The new Article VI language was not intended to supplant that of the 1861 Constitution, but to provide "conceptual definition to the broad but

\footnotetext{
41. See USD 229, 885 P.2d at 1175 ("Act for the Admission of Kansas Into the Union, $\S 3$ (1861), included provisions providing that certain sections of land be reserved for educational purposes.").

42. KAN. CONST. art. VI, $\S 4$ (1861).

43. Berger, supra note 39 , at 3.

44. Id. at 4 .

45. Id. at 5 .

46. Id.

47. Id.

48. Id.

49. Id.

50. Id. at 8 .

51. Id.
} 
vague mandates of the first Constitution." 52 To be candid, the new language served to ensure local control of schools while making it clear that the legislature was in charge of shaping the "general course of public education and [providing] for its financing." 53 The result of all this careful balancing of interests was a complete replacement of the 1861 Article VI language, but not its principles. ${ }^{54}$ The school finance language adopted in 1966 is that which we still use today: "The legislature shall make suitable provision for finance of the educational interests of the state." ${ }^{55}$ Public education has changed many times throughout the state's life, and it will certainly continue to change, but Kansans' dedication to educating all our children remains steadfast.

\section{B. Nationwide School-Finance Litigation: Three Waves of Thought}

Commentators speak of the nation's experience with school-finance litigation as coming in three waves: Federal equity, state-based equity, and adequacy. ${ }^{56}$ Equity litigation focuses on funding inequality between school districts that was caused by disparity in property values. ${ }^{57}$ Adequacy litigation, on the other hand, focuses on the level of funding the state provides to all schools, regardless of relative district wealth or equitable distribution. ${ }^{58}$

The first wave, federal equity litigation, was short lived. Early equity advocates were inspired in part by the Supreme Court's equal protection rulings regarding racial desegregation. ${ }^{59}$ In the 1960 s education advocates began attacking state school finance systems under the Fourteenth Amendment. ${ }^{60}$ The seminal, and last, federal equity case came out of Texas-Rodriguez v. San Antonio started in federal court in 1968 and ended with the Supreme Court in $1973 .{ }^{61}$ The Rodriguez

\footnotetext{
52. $I d$

53. Id.

54. $I d$.

55. KAN. CONST. art. VI, § 6(b).

56. Deborah A. Verstegen, Towards a Theory of Adequacy: The Continuing Saga of Equal Educational Opportunity in the Context of State Constitutional Challenges to School Finance Systems, 23 St. Louis U. PuB. L. ReV. 499, 506 (2004).

57. Richard E. Levy, Gunfight at the K-12 Corral: Legislative v. Judicial Power in the Kansas School Finance Litigation, 54 U. KAN. L. REV. 1021, 1026-27 (2006).

58. Id. at 1033 .

59. ERic A. Hanushek \& Alfred A. Lindseth, Schoolhouses, Courthouses, And Statehouses: Solving the Funding-ACHIEVEment PuZZle in AmericA's Public Schools 88 (2009).

60. Id. at 89 .

61. Id.
} 
plaintiffs argued that using local property taxes to fund schools created funding disparities based solely on wealth and violated students' fundamental right to education. ${ }^{62}$ At the time, a few Supreme Court opinions had hinted at the idea that wealth may create a suspect class requiring heightened scrutiny under the Equal Protection Clause. ${ }^{63}$ However the Court rejected plaintiffs' argument, holding that wealth is not a suspect class and the state only needed a rational basis for establishing the school-funding system it had-a standard easily met by state defendants. ${ }^{64}$ The Court also rejected the idea that education was a federal fundamental right, ${ }^{65}$ marking the end of school-finance litigation's first wave.

Equity advocates did not give up, however, turning instead to state courts-beginning the second wave of school-finance litigation. ${ }^{66}$ Unlike the Federal Constitution, state constitutions often include education clauses. ${ }^{67}$ Advocates began arguing that their state constitutions required equitable school funding and enjoyed some success. ${ }^{68}$ Plaintiffs in sixteen states achieved success either in the courts or through a settlement before the case reached the state supreme court. ${ }^{69}$ The goal of these cases was to decrease inequity in funding between school districts by bringing the bottom up. ${ }^{70}$ Unfortunately, not all states' solution for equity problems had the degree of impact that advocates were looking for. ${ }^{71}$ By the 1990 s the second wave of schoolfinance litigation had lost favor and a new type of litigation began to appear. $^{72}$

The third, and current, wave of school-finance litigation focuses on funding adequacy. ${ }^{73}$ Again, advocates' focus is on state-by-state litigation, finding an argument under state constitutions. ${ }^{74}$ State courts that found adequacy justiciable have found that their constitutions' education provisions "impose an affirmative duty upon the state's

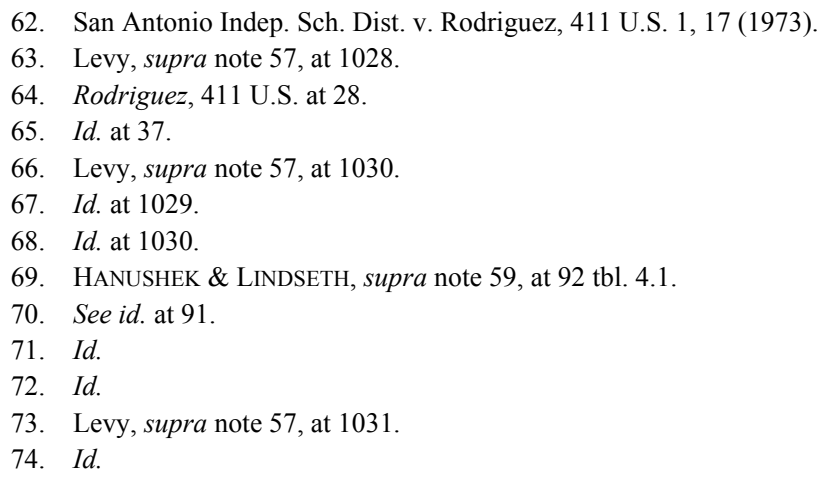


legislature to provide an education." v. Council for Better Education, Inc., came out of Kentucky in 1989. ${ }^{76}$ The Kentucky Constitution requires the legislature to "provide for an efficient system of common schools throughout the State."77 The Rose plaintiffs argued that funding for Kentucky public schools was inadequate overall, even in the wealthiest twenty percent of districts. ${ }^{78}$ The Kentucky Supreme Court focused on the constitution's requirement of an "efficient" school system. ${ }^{79}$ The court held that for the school system to be efficient it must give students the opportunity for an adequate education, as defined by the seven Rose factors that are discussed in the next section. ${ }^{80}$ Finding the Kentucky school-finance system unconstitutional, the court required the legislature to increase funding and even mandated how property taxes could be levied in a new finance system. ${ }^{81}$ Many advocates in other states were encouraged by the Rose plaintiffs' success and quickly began filing adequacy suits. ${ }^{82}$ In the 1990s and early 2000s plaintiffs in adequacy suits enjoyed great success - in the courts. ${ }^{83}$ However, adequacy suits lost steam in 2005 following judgments for defendants in Texas and Massachusetts. ${ }^{84}$

\section{Kansas School-Finance Litigation: And Miles to go Before we Sleep}

Kansas's tumultuous history with school-finance litigation is par for the course nationally. Kansans started going to the courts for education reform in the 1970 s. $^{85}$ None of the early cases made it to the Kansas Supreme Court; instead, the legislature stepped in and responded to the plaintiffs' concerns. ${ }^{86}$ In one of Kansas's first school funding cases, Caldwell v. Kansas, ${ }^{87}$ the district court found the education-funding system unconstitutional on equal protection grounds. ${ }^{88}$ The legislature

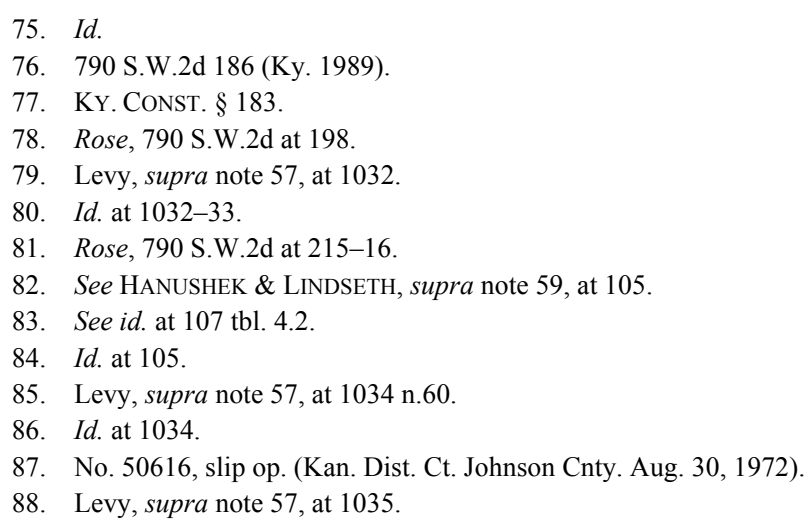


quickly responded, passing the School District Equalization Act and warding off future litigation by the plaintiffs - for the time being. ${ }^{89}$

Over the next twenty years, Kansas school-finance litigation followed much the same path as Caldwell. ${ }^{90}$ It was not until 1994, in Unified School District No. 229 v. Kansas ${ }^{91}$ (USD 229), that the Kansas Supreme Court heard a school-finance case. ${ }^{92}$ In the twenty years since USD 229, the court has heard two protracted school finance cases: Montoy v. Kansas ${ }^{93}$ and the yet unresolved Gannon v. Kansas. ${ }^{94}$

\section{Unified School District No. 229 v. Kansas}

USD 229 was the case that started it all in Kansas. The legislature had responded to early school-finance litigation by enacting the School District Finance and Quality Performance Act (Quality Performance Act). ${ }^{95}$ The Quality Performance Act, which is still in use today, requires school boards to levy a proscribed tax rate on all taxable tangible property within the district in order to support local schools. ${ }^{96}$ The proceeds from this tax generally go to the district's general operating fund, with the portions exceeding the "state financial aid" figure being returned to the state general fund. ${ }^{97}$ The "state financial aid" figure is arrived at by allowing each district a dollar amount per student, determined by the given year's Base State Aid Per Pupil (BSAPP), multiplied by statutory weighting factors that are designed to provide additional resources to underprivileged districts and students. ${ }^{98}$

USD 229 was brought in response to the Quality Performance Act. ${ }^{99}$ Plaintiffs argued that, among other things, the Quality Performance Act did not provide suitable funding and violated the state's equal protection

\footnotetext{
89. $I d$.

90. See id. at 1035-37 (discussing cases from 1972 to 1994).

91. 885 P.2d 1170 (Kan. 1994).

92. Levy, supra note 57, at 1034, 1038.

93. Montoy v. Kansas (Montoy I), 62 P.3d 228 (Kan. 2003).

94. Gannon v. Kansas, 319 P.3d 1196 (Kan. 2014).

95. Levy, supra note 57, at 1034.

96. Unified Sch. Dist. No. 229 v. Kansas, 885 P.2d 1170, 1178 (Kan. 1994).

97. Id.

98. Id. Weighting factors affect the aid a school receives by proscribing a number by which to multiply the BSAPP. This number corresponds to the number of students a school district has that falls within a category that the legislature has deemed in need of extra resources, such as bilingual students, at-risk students, low-enrollment districts, and so on. See KAN. STAT. AnN. §§ 72-6411 to -6415a (2013), repealed by Act of Apr. 2, 2015, ch. 4, 2015 Kan. Laws S.B. 7 (listing weighting factors and how they are used in the Quality Performance Act).

99. USD 229, 885 P.2d at $1178,1182$.
} 
clause. ${ }^{100}$ The court held that the Kansas Constitution's mandate that the legislature provide "suitable provision for finance" "101 was similar to other states' constitutional requirements of adequacy. ${ }^{102}$ However, the court refrained from articulating an adequacy standard stating that "[it] is well settled that courts should not substitute judicial judgment for educational decisions and standards." ${ }^{103}$ Instead of crafting judicial adequacy standards, the court deferred to the legislature's accreditation standards that applied to all Kansas public schools. ${ }^{104}$ The legislature's accreditation standards were similar to judicially created adequacy standards from other states and provided a fool-proof method of determining whether funding to a school was adequate-was the school accredited? ${ }^{105}$ In addition to upholding the Quality Performance Act as adequate, the court rejected the plaintiffs' equal protection challenge finding that school finance is a complex issue on which the legislature should be given great deference and that, in this case, the Act bore a reasonable relationship to the legislature's Article VI duties. ${ }^{106}$ The Kansas school finance scheme survived USD 229, but it would not last long.

\section{Montoy v. Kansas}

In 1999, the Quality Performance Act inspired another court challenge, this time in Montoy v. Kansas. ${ }^{107}$ The Montoy plaintiffs challenged the Quality Performance Act on many grounds. First, plaintiffs alleged that the Act created wealth-based disparity between districts violating equal protection. Second, they alleged that these funding disparities lacked any rational basis to a legitimate state interest. And finally, the plaintiffs argued that the Quality Performance Act failed to provide funding to finance an adequate education for all students, violating the suitability provision of Article VI. ${ }^{108}$ It would not be unjust to call Montoy v. Kansas the case that would not end-it spanned four iterations over seven years. An understanding of Montoy's winding path

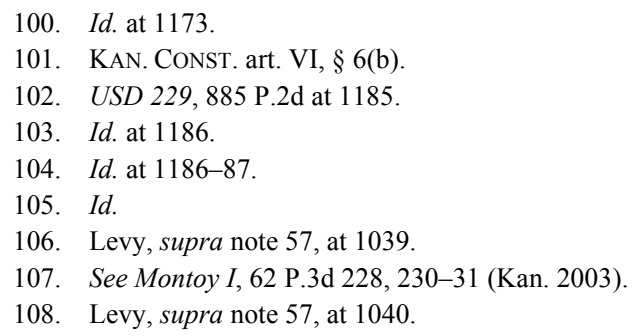


is necessary before attempting to decipher Kansas's most recent schoolfunding decisions.

Montoy I can be dispensed with rather quickly. In light of USD 229's ruling that the Quality Performance Act was constitutional, the trial court in Montoy I dismissed all of plaintiffs' claims. ${ }^{109}$ The Kansas Supreme Court, however, reversed the trial court's ruling stating that USD 229 had clearly stated that the requirements of suitability under Article VI were not stagnant and could change with time. ${ }^{110}$ Plus, the legislative goals that the court in USD 229 had relied on to find the Act constitutional were no longer part of the State's education-finance laws. ${ }^{111}$ Accordingly, the court remanded the case back to the trial court. $^{112}$

Then came Montoy II. Interestingly, the trial court in Montoy II created a judicial standard for determining whether funding was adequate under Article VI's suitability provision. ${ }^{113}$ The trial court noted that the standard was crafted in "the absence of any appellate court or even legislative suitability standard" seeing as the goals relied on in USD 229 had been repealed. ${ }^{114}$ The case was appealed to the Kansas Supreme Court where the plaintiffs' equal protection claims were dismissed because the Quality Performance Act did not create suspect classifications ${ }^{115}$ or have a discriminatory purpose. ${ }^{116}$

The supreme court did, however, find that the Act failed to provide suitable funding to public schools and was unconstitutional because its weighting factors and other provisions were not based on the actual costs of providing students with an adequate education. ${ }^{117}$ The court also discussed how the Quality Performance Act's infirmities forced middleand large-sized districts with high populations of at-risk or disadvantaged students to rely on local-property tax revenue for general education

109. Caleb Stegall, Kan. Policy Inst., A Kansas Primer on Education Funding VOLUME II: ANALYSIS OF MONTOY VS. STATE OF KANSAS 8 \& n.31 (2009).

110. Id. at 11.

111. Montoy $I, 62$ P.3d at 234 .

112. Id. at 235-36.

113. Stegall, supra note 109, at 12 (the "total school funding must be such that it provides every Kansas student, commensurate with their natural abilities, the knowledge and skills necessary to understand and successfully participate in the world around them both as children and later as adults.").

114. Id. at $12-13$.

115. "A statutory classification based on race, national origin, or alienage, and thereby subject to strict scrutiny under equal-protection analysis." BLACK's LAW DICTIONARY 1675 (10th ed. 2014).

116. Montoy v. Kansas (Montoy II), 120 P.3d 306, 308 (Kan. 2005).

117. Id. at $308-09$. 
funding when it was meant only for extra expenses. ${ }^{118}$ This discussion touched on the inequities created by the Act, but was not the basis for the court's ultimate decision that the Act failed to provide finance for an adequate education. ${ }^{119}$ The court stayed the effects of its decision in order to give the legislature time to amend the Quality Performance Act to comply with the court's opinion. ${ }^{120}$

Although, the legislature amended the Quality Performance Act in an attempt to comply with Montoy II, appropriating an additional $\$ 142$ million for schools, that did not satisfy the court in Montoy III. ${ }^{121}$ Again, the court held that the Act violated the suitability provision of Article VI. ${ }^{122}$ The court found that, as amended, the Quality Performance Act's weighting factors still exacerbated, or failed to minimize, inequities between districts and that an adequate amount of funding still had not been appropriated. ${ }^{123}$ The amount of funding required was controlled by a study the legislature had requested during the early days of the litigation and called for over $\$ 800$ million in additional funding. ${ }^{124}$ The court retained jurisdiction over the case, threatening to enjoin the Quality Performance Act if the legislature did not take steps to provide an additional \$285 million for the coming year. ${ }^{125}$ Thus ended Montoy III.

Montoy $I V$, the final Montoy, came after a time of strife between the legislature and court that was caused by the court's ruling in Montoy III. ${ }^{126}$ During a special session in July of 2005 , the legislature finally reached a consensus and passed a school-funding bill that satisfied the court-for the time being. ${ }^{27}$ The last-minute bill called for an additional \$285 million for the 2005-2006 school year. ${ }^{128}$ Though this amount was exactly what the legislature had been ordered to authorize, the court retained jurisdiction of the case to ensure the coming year's schoolfunding bill was also adequate. ${ }^{129}$

Montoy IV was not dismissed until the Kansas Supreme Court found that the legislature had substantially complied with its order in July of

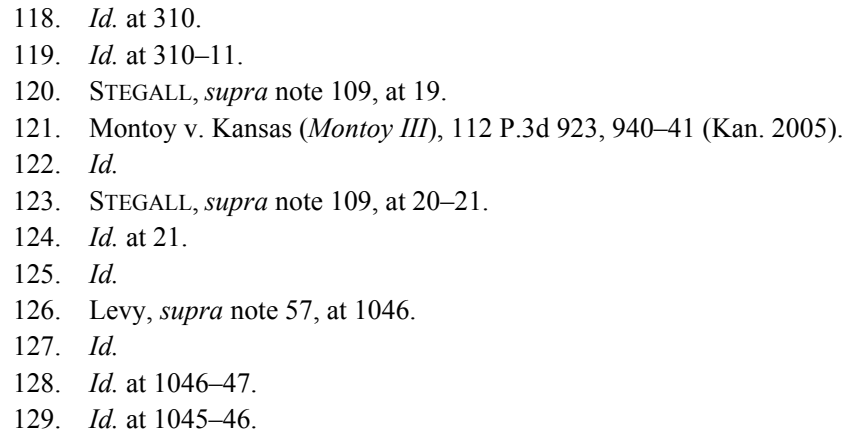


2006 and that the new funding formula was so altered from that in Montoy $I$ that it was no longer properly before the court. ${ }^{130}$ After seven years the battle was finally over, but most Kansans were left wondering what we had to show for it. The court's opinion in Montoy left many with more questions than answers. The court did not provide a clear test for adequacy and introduced the idea that equitable funding is also required by the Kansas constitution. ${ }^{131}$ These questions would not be resolved for another nine years.

\section{Gannon v. Kansas}

In 2014 the Kansas Supreme Court heard a school-finance case for the third time in twenty years: Gannon v. Kansas. ${ }^{132}$ The Gannon plaintiffs argued that the Kansas legislature failed to provide constitutionally adequate funding for public schools. ${ }^{133}$ The plaintiffs alleged that in reducing or withholding state aid, the legislature created unconstitutional inequity among school districts by forcing schools to rely on the money they could raise through local-property taxesrevenues that vary greatly across the state. ${ }^{134}$

Unlike USD 229 and Montoy, the plaintiffs in Gannon did not challenge the Quality Performance Act itself. ${ }^{135}$ Instead, the Kansas Supreme Court only heard challenges to the State's withholding of capital-outlay aid and the prorating or withholding of state supplementalgeneral aid. ${ }^{136}$ Capital-outlay aid is provided to help districts purchase things like equipment or new facilities. ${ }^{137}$ The amount of capital-outlay aid a district may receive is determined by formula and functions as a way to provide poor districts with state funds in an effort to shrink the spending gap between high and low property-wealth districts. ${ }^{138}$ State supplemental-general aid utilizes a slightly different formula but serves the same purpose - to better equalize spending power between high and low property-wealth districts. ${ }^{139}$

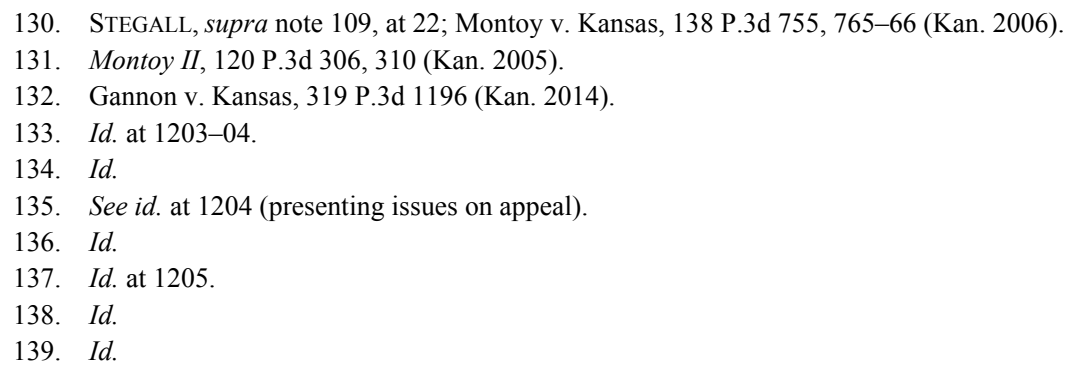


The Kansas Supreme Court's opinion in Gannon answered many of Montoy's lingering questions. Namely, Gannon created clear tests for adequacy and equity in school-finance litigation. ${ }^{140}$ The Gannon court also explained that the state's school-finance system must pass both the adequacy and equity tests to be constitutional. ${ }^{141}$ But, before the court could reach the merits it had to address the justiciability issues not litigated in Montoy or USD 229. ${ }^{142}$

Montoy's aftermath illustrated just how much tension school-finance litigation can create between the court and legislature. That tension came front and center in the Gannon court's opinion. A considerable amount of the court's time was spent analyzing whether adequacy was a nonjusticiable political question requiring the court to infringe on the legislature's powers. ${ }^{143}$ The State argued that adequacy was nonjusticiable because school funding was constitutionally committed to the legislature and the court lacked judicially discoverable and manageable standards by which to judge whether the Quality Performance Act provided adequate funding. ${ }^{144}$ The Gannon court relied heavily on a school finance case from Texas when finding that the adequacy challenge did not present a non-justiciable political question. ${ }^{145}$ The court reasoned that the Kansas Constitution provided all the standards necessary to decide whether the state was adequately funding education or not, pointing the vague goal of "improvement" found in Article VI, Section One as the basis of their decision. ${ }^{146}$ In arriving at the conclusion that the vague goals of Section One provided standards enough, the court quickly noted that it is used to defining or applying vague or imprecise constitutional standards. ${ }^{147}$

Upon reaching the merits, the court first clarified its previous holdings regarding adequacy. ${ }^{148}$ In Montoy, the court had approvingly quoted Rose v. Council for Better Education, ${ }^{149}$ but did not adopt its

\footnotetext{
140. Id. at 1236, 1239; see also infra notes 152, 158 and accompanying text.

141. Id. at 1233 .

142. Id. at 1216 .

143. Id. at $1216-31$.

144. Id. at $1224-25$.

145. Id. at $1225-26$.

146. Id.

147. Id. at 1228 .

148. Id. at 1233 .

149. 790 S.W.2d 186 (Ky. 1989).
} 
adequacy test. ${ }^{150}$ Rose outlined the following seven competencies required for an adequate education under the Kentucky Constitution:

(i) sufficient oral and written communication skills to enable students to function in a complex and rapidly changing civilization;

(ii) sufficient knowledge of economic, social, and political systems to enable the student to make informed choices;

(iii) sufficient understanding of governmental processes to enable the student to understand the issues that affect his or her community, state, and nation;

(iv) sufficient self-knowledge and knowledge of his or her mental and physical wellness;

(v) sufficient grounding in the arts to enable each student to appreciate his or her cultural and historical heritage;

(vi) sufficient training or preparation for advanced training in either academic or vocational fields so as to enable each child to choose and pursue life work intelligently; and

(vii) sufficient levels of academic or vocational skills to enable public school students to compete favorably with their counterparts in surrounding states, in academics or in the job market. ${ }^{15}$

After a lengthy comparison to the Kansas legislature's own educational goals, the court adopted the seven Rose factors as the minimum test for adequacy under Article VI. ${ }^{152}$ The court then remanded the adequacy issue, instructing the trial court to determine whether the school-finance system was reasonably calculated to have Kansas public-school students meet the Rose factors. ${ }^{153}$ The trial court recently found that "the Kansas public education financing system ... is not presently reasonably calculated to have all Kansas" students meet the Rose factors. ${ }^{154}$ At the time of publication, how the State and courts will proceed is up in the air and, yet again, tensions are mounting between the legislature, executive, and judiciary. ${ }^{155}$

\footnotetext{
150. Gannon, 319 P.3d at 1233.

151. Id. (quoting Rose, 790 S.W.2d at 212).

152. Id. at 1236.

153. Id. at $1237-38$.

154. Gannon v. Kansas, No. 2010CV1569, at*114-15 (Dist. Ct. Shawnee Cnty. Dec. 30, 2014) (on file with author).

155. E.g., Bryan Lowry, Brownback Team Blasts Coverage of Kansas School Funding Decision,
} 
Prior to Gannon, the Kansas Supreme Court had alluded to requiring equitable funding distribution under Article VI, but had not developed a test or standard by which to determine whether funding was in fact equitable. ${ }^{156}$ Unlike adequacy, the court quickly arrived at an equity test. The court briefly cited previous cases expressing dissatisfaction with inequitable distribution of funds and the legislature's own concern with education's inequitable tax burden before adopting an equity test for school finance under Article VI. ${ }^{157}$ Now, the Kansas school-finance system must ensure that school districts "have reasonably equal access to substantially similar educational opportunity through similar tax effort." ${ }^{\text {"158 }}$ Also unlike the adequacy issue, the court applied this new equity test to the merits of the case. ${ }^{159}$ The court found that the State's reduction or withholding of supplemental-general aid and capital-outlay aid violated the equity test by creating unreasonable wealth-based disparity between school districts and was therefore unconstitutional. ${ }^{160}$ It was left to the legislature to determine how best to rectify the inequity its actions had created. ${ }^{161}$ In April 2014, the Kansas legislature passed a $\$ 129$ million funding package in an effort to comply with the Gannon court's equity ruling. ${ }^{162}$ Two months later, the trial court ruled that the new funding was sufficient to meet Gannon's equity requirements, ending the equity leg of the litigation. ${ }^{163}$

The nationwide waves of school-finance litigation can be seen in the evolution of Kansas's own struggle. In 1994, USD 229 failed in its

\footnotetext{
THE KANSAS City STAR (Feb. 7, 2015, 5:09 PM), www.kansascity.com/news/local/news-columnsblogs/the-buzz/article9524750.html; Bryan Lowry, Gov. Sam Brownback's Push to Change Kansas Supreme Court Seen as Linked to School Finance, Wichita EAGLE (Jan. 24, 2015, 4:46 PM), www. kansas.com/news/politics-government/article8071974.html [hereinafter Push to Change Kansas Supreme Court]. Governor Brownback recently signed a funding bill into law that repeals the entire Quality Performance Standards Act, prompting the Gannon plaintiffs to file a petition with the threejudge panel to stay the bill's effects pending the court's final decision. Bryan Lowry, Districts Try to Block Kansas School Funding Law, The Tribune News Service (Mar. 30, 2015), http://www.governing.com/topics/education/tns-kansas-school-funding-lawsuit.html [hereinafter Districts Try to Block School Funding Law].

156. See Gannon, 319 P.3d at 1238 (discussing cases considering equity but not adopting a standard).

157. Id. at $1238-39$.

158. Id. at 1239 .

159. Id.

160. Id. at 1239,1243 .

161. Id. at $1243,1247$.

162. Judges Say Kansas School Funding Law Meets Mandate, KAnSAs City STAR (June 11, 2014, 8:38 PM), www.kansascity.com/news/government-politics/article528607/Judges-say-Kansasschool-funding-law-meets-mandate.html [hereinafter School Funding].

163. Id.
} 
equity challenge. Then, in 1999, Montoy began its fight for adequacy, culminating in a win for the state in 2006. Finally, we arrive at Gannon, a hybrid of the two state-based waves but clearly focused on funding adequacy. Where Kansas will go from here is still unclear, but one thing is for sure-school-finance litigation is here to stay.

\section{ANALYSIS}

Gannon's adoption of a vague equity test provides advocates fertile ground for achieving greater equity among Kansas school districts. Whereas the Gannon court's adequacy decision opened the floodgates to a world of judicial problems by reading Article VI as requiring the legislature to provide enough additional funding to create an "adequate" 164 public education. First I consider the non-justiciability of, and practical problems with, adequacy litigation; then I move on to examining the benefits of framing Gannon's equity test as requiring vertical equity in school funding.

\section{A. Adequacy: A Study in Non-Justiciability}

Adequacy litigation poses many legal and practical problems that render the theory irreconcilably flawed. Like many other state courts, the Kansas Supreme Court entertained an adequacy challenge all the while saying that determining the level of education spending is beyond its responsibility. ${ }^{165}$ Such courts overlook the fact that "adequacy cases by their very nature move courts into the policy arena" by forcing the judiciary to develop remedies historically in the purview of the legislature. ${ }^{166}$ The Gannon court's treatment of adequacy overlooked the serious problems that come with creating policy in the guise of judicial remedies.

\section{Wherefore Art Thou A Political Question?}

Adequacy challenges to education funding under Article VI of the Kansas Constitution are non-justiciable political questions. The political question doctrine is a non-justiciability doctrine based on separation of

\footnotetext{
164. Throughout the rest of this discussion any reference to "suitable" should be read to mean "adequate."

165. HANUSHEK \& LINDSETH, supra note 59 , at 96.

166. Id. at $95-96$.
} 
powers principles. ${ }^{167}$ Although it is widely recognized that "separation of powers of government has never existed in pure form except in political theory," 168 the political question doctrine is a tool developed by the courts to protect the coordinate branches against ever being "controlled by, or subjected, directly or indirectly, to, the coercive influence of either of the other departments."169 To that end, Kansas adopted the Supreme Court's political question test found in Baker v. Carr. $^{170}$

A non-justiciable political question is present when one or more of the following Baker factors exists:

[A] textually demonstrable constitutional commitment of the issue to a coordinate political department; or a lack of judicially discoverable and manageable standards for resolving it; or the impossibility of deciding without an initial policy determination of a kind clearly for nonjudicial discretion; or the impossibility of a court's undertaking independent resolution without expressing lack of the respect due coordinate branches of government; or an unusual need for unquestioning adherence to a political decision already made; or the potentiality of embarrassment from multifarious pronouncements by various departments on one question. ${ }^{171}$

Litigation focusing on adequacy in school funding meets several of Baker's factors for non-justiciability. To begin, the adequacy of school funding is committed to the legislature, as supported by the lack of judicially discoverable and manageable standards. Further, deciding an adequacy case would require the court to make a preliminary policy decision that defines what an adequate education in Kansas is, thereby showing a lack of respect for a coordinate branch - the legislature.

a. As you wish - a constitutional commitment of school finance decisions

The Kansas Constitution commits education-funding decisions to the legislature. Article VI, Section Six commands that the "legislature shall

167. Leek v. Theis, 539 P.2d 304, 327 (Kan. 1975).

168. Id. at 321 (citing State ex rel. Taylor v. Mo. Pac. Ry. Co., 92 P. 606, 608 (Kan. 1907), aff'd, 216 U.S. 262 (1910)).

169. Id. at 322 (emphasis omitted) (quoting O’Donoghue v. United States, 289 U.S. 516, 530 (1933)).

170. Van Sickle v. Shanahan, 511 P.2d 223, 234 (Kan. 1973) (citing Baker v. Carr, 369 U.S. 186 (1962)).

171. Baker, 369 U.S. at 217. 
make suitable provision for finance of the educational interests of the state." The Kansas Constitution defines the state's educational interests in Article VI, Section One: "The legislature shall provide for intellectual, educational, vocational and scientific improvement by establishing and maintaining public schools ...." The constitution further commands that it is the legislature who shall organize the public schools and grants the legislature the power to change schools "in such manner as may be provided by law." ${ }^{\prime 72}$ Reading these provisions together and giving them their plain meaning, as we are commanded to do, ${ }^{173}$ it is clear that the Kansas Constitution places the duty to fund schools on the legislature alone.

It is true that the Kansas Constitution both "empowers and obligates" $"$ the legislature to provide funding sufficient to ensure an adequate education for public school children. And it would be inconceivable to argue that such an obligation does not give rise to a duty enforceable by law. However, it is not the duty to fund schools that adequacy advocates challenge, but the manner in which the legislature chooses to do so - a very different matter indeed. When the Kansas Constitution solely empowered the legislature to "make suitable provision for finance" 175 it did not place any restrictions on how the legislature was to do so, the constitution merely directed the legislature to provide funding in such a way as to attain the state's educational interests. ${ }^{176}$ By leaving it to the legislature to determine what policies will achieve the constitution's goals of "intellectual, educational, vocational and scientific improvement," the constitution is leaving to the legislature the decision about how best to fund schools in order to achieve those goals. It is well-settled law that discretionary actions performed by a coordinate branch of government are considered political in nature, and are not to be disturbed by the judiciary. ${ }^{177}$ Had the constitution placed limits or requirements on how the legislature was to attain the state's educational interests, it would be another matter entirely. ${ }^{178}$ But here that is not the case. The Kansas Constitution leaves

172. KAN. CONST. art. VI, § 1.

173. See Gannon v. Kansas, 319 P.3d 1196, 1221 (Kan. 2014) (explaining that the only safe way to interpret a constitution is to give its words their plain meaning).

174. Id. at 1139 (quoting Neeley v. West Orange-Cove, 176 S.W.3d 746, 778 (Tex. 2005)).

175. KAN. CONST. art. VI, $\S 6$.

176. See KAn. CONST. art. VI, $\S \S 6,1$ (articulating the state's educational interests).

177. Marbury v. Madison, 5 U.S. 137, 165-66 (1803).

178. See id. at 166 ("when the legislature proceeds to impose on that officer other duties; when he is directed peremptorily to perform certain acts; when the rights of individuals are dependent on the performance of those acts; he is so far the officer of the law; is amenable to the laws for his 
it to the legislature to determine how, and thereby how much, to fund public schools. Such a textual commitment weighs strongly against the justiciability of adequacy in Kansas.

b. Suitable is to discoverable as light is to dark

That the adequacy of school funding is textually committed to the legislature is further bolstered by the concept's lack of judicially discoverable and manageable standards. ${ }^{179}$ Judicially discoverable standards are lacking if constitutional text and history do not provide the court with standards by which to review the actions of another branch or if the constitutional text "lacks sufficient precision to afford... [a] standard of review." 180 In addition, courts have considered the lack of qualitative standards, especially in the realm of school-finance litigation, to indicate a lack of judicially discoverable and manageable standards. ${ }^{181}$

The Kansas Constitution fails to provide qualitative standards, it merely sets the goal toward which the legislature should aspire in providing funding - the educational improvement of Kansas children. Article VI requires the legislature to make "suitable provision for finance" 182 for the state's educational interests, which are broadly defined as "intellectual, educational, vocational and scientific improvement." The constitution does not go on to ascribe standards by which to measure "improvement"- that is left to the legislature. Because the constitution does not define "improvement," it does not tell the legislature what it is supposed to provide "suitable provision for finance" for. The vagueness of Article VI has left the court without a guide for what "suitable provision of finance" means; ${ }^{184}$ thereby leaving the judiciary without a textual standard against which to weigh the legislature's appropriation decisions and without a textual standard for what the framer's intended "suitable" to mean.

conduct; and cannot at his discretion sport away the vested rights of others.").

179. See Nixon v. United States, 506 U.S. 224, 228 (1993) ("the lack of judicially manageable standards may strengthen the conclusion that there is a textually demonstrable commitment to a coordinate branch.").

180. Van Sickle v. Shanahan, 511 P.2d 223, 234 (Kan. 1973); Id. at 230.

181. See, e.g., Neb. Coal. for Educ. Equity \& Adequacy v. Heineman, 731 N.W.2d 164, 179 (Neb. 2007) (finding that a lack of constitutional, qualitative standards weighs heavily against justiciability in school-finance litigation).

182. KAN. CONST. art. VI, § 6.

183. KAN. CONST. art. VI, § 1.

184. Kan. Const. art. VI, § 6; see also Unified Sch. Dist. No. 229 v. Kansas, 885 P.2d 1170, 1186 (Kan. 1994) (discussing the vague nature of the term "suitable" in Article VI). 
In addition to lacking textual standards, the term "suitable" is too vague to provide the court with any meaningful standard on which to base a determination. In fact, the Kansas Supreme Court recognized the lack of judicially discoverable standards for adequacy in USD 229. There, the court affirmed the district court's finding that suitability permitted of many varying definitions and did not "imply any objective, quantifiable education standard against which schools can be measured by a court." " ${ }^{\text {"185 }}$ As previously discussed, the court in USD 229 deferred to the legislature's definition of suitability as enacted in the school accreditation requirements. ${ }^{186}$ The court did not adopt the legislature's definition; instead, it reasoned that all schools meeting the legislature's accreditation requirements were being suitably funded. ${ }^{187}$ The Kansas Supreme Court in USD 229 did not purport to define "suitable" as it exists in the constitutional text. Instead, the court relied on the legislature's definition of an adequate education - suitable was, and is, too vague a term to prop up a judicial doctrine.

The Gannon court was also without historical precedent as a basis for reviewing the legislature's actions. ${ }^{188}$ Although suitability had been touched upon in USD 229 and Montoy, the court had never heard arguments against its justiciability. ${ }^{189}$ With no aid from constitutional text, common understanding of the term "suitable," or reliable historical precedent-Gannon had to fabricate adequacy standards. However, the Baker factor does not ask if the court can fabricate a judicially manageable standard, it asks if one is discoverable.

c. What came first, the judicial decision or a policy determination?

Perhaps one of the more troubling aspects of Kansas adequacy litigation is that it requires the court to make a policy determination before it can rule. When the court is asked to rule on the wisdom of the legislature's appropriations, it is asked to make a policy determination that is outside the judiciary's powers. ${ }^{190}$ Only questions concerning the legality of appropriations are justiciable. Modern adequacy litigation

\footnotetext{
185. USD 229, 885 P.2d at 1185.

186. See supra Part II.B.

187. See USD 229, 885 P.2d at 1186 (Kan. 1994) (stating that the Quality Performance Act set out standards schools must meet and the evidence showed that all had).

188. See Gannon v. Kansas, 319 P.3d 1196, 1217 (Kan. 2014) (stating that non-justiciability of school finance provisions in the state constitution was a question of first impression in the state).

189. Id

190. Massachusetts v. Laird, 400 U.S. 886, 893 (1970).
} 
asks the court to pass judgment on the wisdom of the legislature's school funding appropriation without adequate legal standards to do so.

As previously stated, the Kansas Constitution does not provide the legislature, or the judiciary, with a rubric for achieving the state's educational goals. ${ }^{191}$ So, one is left to wonder: Did the legislature provide "suitable provision of finance" for what? The state's educational interests. What are the state's educational interests? Improvement. What is required to attain "improvement?" I do not know, the constitution does not say.

Here is where the court arrives at the chicken-and-the-egg conundrum. The court does not have a standard against which to judge whether the legislature has made "suitable provision for finance." In order, then, to decide whether school funding is suitable the court must first determine what form of education will meet the Kansas Constitution's goals of improvement-thereby making a policy determination. ${ }^{192}$ Without this initial policy determination, the court would not have a guide for what kind of education the constitution requires, which means the court could not determine how much money is required to provide "suitable provision for finance."

d. Well now that was embarrassing ...

If meeting the preceding three Baker factors was not enough, adequacy litigation poses a nearly certain potential for "embarrassment from multifarious pronouncements by various departments on one question."193 Adequacy litigation in Kansas has led to years of back-andforth between the courts, legislature, and even governor. ${ }^{194}$ If Kansas's own troubles are not enough to illustrate the potentiality for embarrassment, New Jersey and New York's experiences paint a pretty clear picture. ${ }^{195}$

New Jersey's fight for adequacy in education funding began with Abbott v. Burke, and has continued in its courts for nearly fifteen

191. See discussion supra Part II.A.1.

192. See Gannon, 319 P.3d at 1236-37 (adopting the Rose factors and clarifying "what Article 6 of our constitution requires," and remanding to determine whether Rose factors are met).

193. Baker v. Carr, 369 U.S. 186, 217 (1962); see also Van Sickle v. Shanahan, 511 P.2d 223, 234 (Kan. 1973).

194. Supra Part II.A.2.

195. Abbott v. Burke, 710 A.2d 450 (N.J. 1998); Campaign for Fiscal Equity, Inc. v. New York, 861 N.E.2d 50 (N.Y. 2006). 
years. ${ }^{196}$ The Abbott litigation began as an adequacy case in $1998 .{ }^{197}$ The New Jersey Supreme Court required an adequacy standard be met in particular underprivileged districts, called the Abbott districts. ${ }^{198}$ As of 2005 "the Abbott districts received approximately 57 percent of all state aid for K-12 education in New Jersey, even though they only enroll about 20 percent of the state's pupils." ${ }^{199}$ As of 2011, the Abbott plaintiffs were still litigating the adequacy issue in state court. ${ }^{200}$

New York's seminal adequacy case began in 1993, led by the Campaign for Fiscal Equity (CFE). ${ }^{201}$ The first CFE case resulted in the court requiring New York to fund a "basic" education. ${ }^{202}$ The case was remanded for the trial judge to determine what level of funding would meet the state's new adequacy standard. ${ }^{203}$ The trial judge ordered the state to increase education funding by $\$ 23$ billion in five years. ${ }^{204}$ Over the next thirteen years, the case moved from court to court until, finally in 2006, the New York Court of Appeals significantly lowered the amount due by the state. ${ }^{205}$ In an interesting turn of events, the Governor and legislature came together and negotiated a settlement that satisfied all parties. ${ }^{206}$ After nearly thirteen years of litigation, "plaintiffs finally got what they wanted through the political process they had so diligently attacked in court as broken" when the newly elected governor brokered a deal within the legislature to fund New York City schools at nearly four times what the court had ordered. ${ }^{207}$ It would be unjust to attribute CFE's resolution entirely to the political process, as the protracted litigation surely contributed to the legislature's willingness to increase funding. However, the political resolution to New York's educationlitigation woes illustrates the necessity of legislative buy-in - a scenario made less likely with the hearing of each new adequacy case.

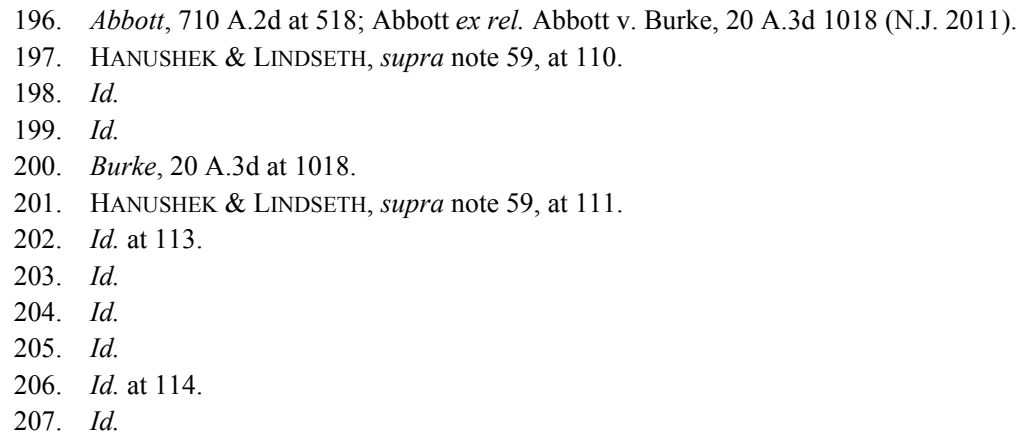


e. There will be little rubs and disappointments everywhere, especially in politics

Proponents of adequacy litigation argue that the issue does not present a political question. After all, financing for public schools is in the constitution. ${ }^{208}$ And, as Chief Justice Marshall wrote over 200 years ago, it is "emphatically the province and duty of the judicial department to say what the law is." 209 Alas, sometimes "the law is that the judicial department has no business entertaining the claims ..." brought before it. $^{210}$

The Gannon court argued that because at some point funding could be so low as to clearly be unsuitable, there was no political question. ${ }^{211}$ Though calculated to be persuasive, such reasoning does not require a finding that the term "suitable" provides judicial standards or that adequacy challenges under Article VI do not pose political questions. Kansas citizens are not completely without judicial recourse under Article VI. If the legislature was to completely forgo funding public schools or to fund them at such abhorrently low levels that its appropriation bore no reasonable relationship to educational improvement, a challenge under Article VI could be justiciable. The term "suitable" does not impose a textual limit on the legislature's authority to set school finance policy, but the constitution's use of the word "shall" requires the legislature to fund schools. ${ }^{212}$ Judging whether the legislature is providing funding to schools is not a political question, the political question arises when adequacy litigation asks the court to pass judgment on the wisdom of the legislature's appropriations. Thus presenting a non-justiciable political question.

208. KAN. CONST. art. VI.

209. Marbury v. Madison, 5 U.S. 137, 177 (1803).

210. Neb. Coal. for Educ. Equity \& Adequacy v. Heineman, 731 N.W.2d 164, 176 (Neb. 2007) (quoting Vieth v. Jubelirer, 541 U.S. 267, 277 (2004)).

211. See Gannon v. Kansas, 319 P.3d 1196, 1225-26 (Kan. 2014) (discussing whether manageable standards existed to hear the adequacy issue under Article VI).

212. Compare Nixon v. United States, 506 U.S. 224, 237-38 (1993) (holding that the ability to determine how the legislature utilizes its impeachment power is textually committed to that branch and the word "try" did not permit of sufficient definition to provide judicially manageable standards against which the Court could limit the Senate's authority to conduct impeachment proceedings however it wished), with Powell v. McCormack, 395 U.S. 486, 548-49 (1969) (holding that the Constitution was clear in denominating what "qualifications" Congress was able to exclude members for and declining to expand Congress's power beyond what was specifically delimited in the text of the Constitution). 
2. The Practical Problem with Adequacy

Not only does adequacy present the judiciary with a non-justiciable political question, it fails as a remedy. At its roots, the adequacy argument seeks to provide each student with nothing more than "a high minimum." 213 Yes, providing all students with some form of adequate education is laudable, but it fails to achieve the goal of better educating our children - of statewide educational improvement. Adequacy litigation seeks more money, focusing on a false remedy - the money myth. ${ }^{214}$ The call for more funding as the way to fix America's education problem is not new, this debate has been going on since the $1800 \mathrm{~s}^{215}$ But more money alone will not, and has not, fixed the problem. ${ }^{216}$ Inequality in resources and outcomes has not changed as a result of the staggering amount of money poured into school districts, nor has the need for meaningful education reform. ${ }^{217}$

One needs to look no further than Kentucky, adequacy's birthplace, to see that adequacy does not solve education's funding problems. The state legislature enacted the Kentucky Education Reform Act of 1990 (KERA) in response to the Rose decision. ${ }^{218}$ KERA authorized a forty percent increase in spending, a windfall for plaintiffs' cause. ${ }^{219}$ However, student performance did not improve in any significant way. ${ }^{220}$ In fact, between 1992, when the spending increase went into action, and 2007, black Kentucky students actually fell behind the national average in reading and math. ${ }^{221}$ Before the spending increase occurred black students were above the national average in both subjects. ${ }^{222}$ Another study, this one performed in 2003, found that Kentucky would have to spend another $\$ 740$ million per year to meet the state's court-created adequacy standard. ${ }^{223}$ In light of inflation, this number is likely to continue to rise for all of time, with no evidence that increased spending

\footnotetext{
213. William S. Koski \& Rob Reich, When "Adequate" Isn't: The Retreat from Equity in Educational Law and Policy and Why It Matters, 56 EMORY L.J. 545, 590 (2006).

214. W. Norton GrubB, THE MONEY MYTH 262 (2009).

215. Id. at 1 .

216. Id. at 25 .

217. Id.

218. HANUSHEK \& LINDSETH, supra note 59 , at 148 .

219. Id.

220. Id

221. Id. at 149 .

222. Id.

223. Allan Odden et al., A State-OF-The-Art Approach to School Finance Adequacy IN KENTUCKY 39 (2003).
} 
has created a better education for the most disadvantaged Kentucky students. The adequacy trap is an easy one for courts to fall into, but should be avoided at all costs. When courts focus only on adequacy they focus on the total dollars spent on education, distracting the legislature from where the real problems in education lie-inefficiency, curriculum, socioeconomic inequities, and so on.

One commentator noted that, when it comes to adequacy litigation, "[w]ell-intentioned judges have been persuaded to help solve one of the most important... problems the nation faces, aided in large part by plausible-sounding solutions." 224 Providing an adequate education to our children is something of a siren's song-beautiful and alluring, but always a trap. Unfortunately, Kansas has fallen victim to her song and stands poised to follow Kentucky, New Jersey, and New York into the bottomless pit that is adequacy litigation. So if more money does not solve the problem, what will?

\section{B. Equity: A Many-Splendored Thing}

Though Kansas courts had been determining whether school-finance legislation was constitutionally equitable since the 1970s, the state's highest court had not pronounced a cohesive rule. Gannon changed all that. Now, as Kansas legislators craft school-finance policy they must bear the following test in mind: "School districts must have reasonably equal access to substantially similar educational opportunity through similar tax effort."225 At first glance the Gannon test appears so ambiguous as to render it useless: What is substantially similar educational opportunity? Equity advocates, however, may find the test's ambiguity to be its most appealing trait. The Gannon test leaves room to focus on more than one facet of equity and to consider more than money when defining educational opportunity.

Equity litigation does not suffer from the same justiciability problems as adequacy because equity in school finance has been a part of Kansas's history since its territorial constitution. ${ }^{226}$ Although Article VI as we see it today no longer contains the word "equitable," the 1966 revisers of the constitution did not intend to remove the principle. ${ }^{227}$ In fact, equity has been considered part and parcel of Kansas education

224. HANUSHEK \& LINDSETH, supra note 59, at 103.

225. Gannon v. Kansas, 319 P.3d 1196, 1239 (Kan. 2014).

226. Supra Part II.A.

227. Id. 
litigation since the 1950 s with Brown v. Board ${ }^{228}$ and school-finance litigation since the 1970s. ${ }^{229}$ Even if Kansas did not have historical precedent to consider equity cases based on Article VI, it is well known that the courts have a long history of reviewing and resolving equity based litigation. ${ }^{230}$ Furthermore, equity challenges allow the court to utilize equal protection analysis in order to reach and decide the merits. ${ }^{231}$ Therefore it is no surprise that the Gannon court did not waste anytime concerning itself with the justiciability of plaintiffs' equity argument. Now that Kansas courts have adopted an equity test, the question becomes what kind of equity should the courts focus on?

\section{Horizontal and Vertical Equity Defined}

Before proposing what equity should mean in Kansas school-finance litigation, one must first understand what equity is. Equity is a broad concept encompassing many areas but can be generally understood as a "body of principles constituting what is fair and right."232 Equity comes in many forms, but those most important to school finance are horizontal and vertical equity. Horizontal equity aims to decrease disparity between similarly situated school districts. ${ }^{233}$ Vertical equity aims to treat differently situated districts differently by moving the bottom up. ${ }^{234}$ Scholars today believe that horizontal equity should not be the courts' only focus; instead, the courts should focus on vertical equity. ${ }^{235}$

The first and second waves of school-finance litigation focused on horizontal equity. ${ }^{236}$ Much of the dissatisfaction surrounding early equity litigation was the result of misinformation. Many believed that equity litigation resulted in a race-to-the-bottom effect. ${ }^{237}$ This concern was even voiced in Kansas by the USD 229 plaintiffs: "They [plaintiffs] acknowledge [that] there is a wide disparity in per pupil spending but argue the legislature is improperly cutting off the mountain tops to fill in

\footnotetext{
228. Brown v. Bd. of Educ., 347 U.S. 483 (1954).

229. Levy, supra note 57, at 1035.

230. Id. at 1051.

231. See Unified Sch. Dist. No. 229 v. Kansas, 885 P.2d 1170, 1187-90 (Kan. 1994).

232. BLACK'S LAW DictiONARY 656 (10th ed. 2014).

233. HANUSHEK \& LINDSETH, supra note 59, at 58.

234. Robert Berne \& Leanna Stiefel, Concepts of School Finance Equity: 1970 to the Present, in EQUiTy AND AdEQUACY IN EDUCATION FinANCE: IsSUES AND PeRsPeCtives 7, 20 (Helen F. Ladd et al. eds., 1999).

235. Koski \& Reich, supra note 213 , at $608-09$.

236. Id. at $557-58$.

237. Id. at 591 .
} 
the valleys." ${ }^{238}$ However, a study done in the 1990s found that courtordered equity reform actually reduced "inequality by raising spending at the bottom of the distribution while leaving spending at the top unchanged." 239 The second wave's focus on horizontal equity made other positive gains that have gone overlooked by adequacy advocates. ${ }^{240}$ A study done at the height of equity's popularity found that courtmandated school-finance reforms significantly decreased intra-state inequality by encouraging legislatures to increase spending in lower property-wealth districts without needing to decrease funding to the already high property-wealth districts. ${ }^{241}$

Early advocates were attracted to horizontal equity because it treats all students the same, regardless of their home address - something the local-property-tax system does not do. ${ }^{242}$ Unfortunately, this means horizontal equity also does not take relative need into account. ${ }^{243}$ It simply raises all boats. Although the courts' focus on horizontal equity did make gains in improving school finance, the concept could only take them so far. A comprehensive approach to equity demands more than simply reducing inequity between school districts, it requires increasing equity of opportunity.

Vertical equity places the focus on students by identifying groups of children that require more resources in order to receive educational opportunities similar to their peers. ${ }^{244}$ To do this, vertical equity ties input and output equity together, allowing for a more accurate and beneficial distribution of resources. ${ }^{245}$ Input equity is concerned with putting equitable resources into the school system whereas output equity is concerned with creating equity in educational outcomes. ${ }^{246}$ For example, achieving vertical equity would require that students whose first language is not English receive additional resources in order to learn English well enough to succeed in their other classes. In this example the native-English speakers would not receive additional resources from the state while non-native English speakers would receive additional

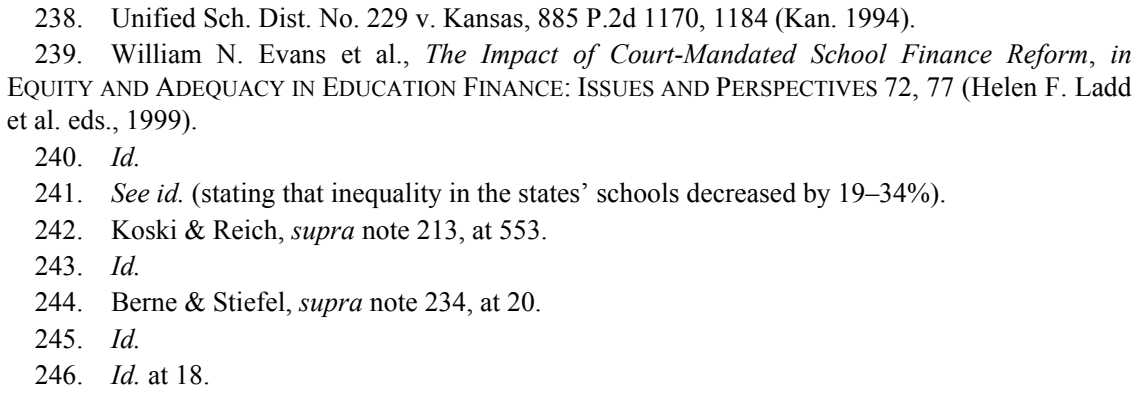


state aid, but both groups would achieve the same outcome-similar opportunity to succeed in classes.

An example of vertical equity in practice can be found in Title I of the Elementary and Secondary Education Act of $1965 .{ }^{247}$ Title I, ${ }^{248}$ formally entitled Improving the Academic Achievement of the Disadvantaged, is federal legislation aimed at increasing equity in education by providing additional funds to school districts with high numbers of students from low-income families. ${ }^{249}$ Another example of vertical equity in practice can be seen, though admittedly imperfectly, in parts of the recently repealed ${ }^{250}$ Quality Performance Act. Many of the Quality Performance Act's weighting factors serve to provide additional funding to schools with high levels of disadvantaged students. ${ }^{251}$ Both of these programs aim to increase equity by providing more to those with the least-vertical equity. Analysts and theorists find vertical equity an appealing solution to many of education finance's problems, but policymakers have been reluctant to institute such reforms. ${ }^{252}$ Why? Because creating an accurate funding formula that considers both what is put into schools and how those resources produce outcomes is difficult, but not impossible. ${ }^{253}$

\section{Equity and Understandings of Educational Opportunity}

Gannon's equity test speaks of equity in "educational opportunity" but does not define it. ${ }^{254}$ Here is where advocates may find the test's ambiguity beneficial. Educational opportunity can encompass any number of resources: money, teachers, technology, classes, the list is endless. Educational opportunity also encompasses several methods of achieving equitable distribution. ${ }^{255}$ There are four ways of looking at

\footnotetext{
247. Id. at 21.

248. 20 U.S.C. $\S 6301$ (2012).

249. Programs: Improving Basic Programs Operated By Local Educational Agencies (Title I, Part A), U.S. DEPT. OF EDUC., http://www2.ed.gov/programs/titleiparta/index.html (last modified June 4, 2014).

250. See Kan. Stat. AnN. §§ 72-6411 to -6415a (2013), repealed by Act of Apr. 2, 2015, ch. 4, 2015 Kan. Laws S.B. 7; see also Districts Try to Block School Funding Law, supra note 155.

251. See supra Part II.C.1.

252. See Berne \& Stiefel, supra note 234, at 20-21.

253. Id. at 21 .

254. Gannon v. Kansas, 319 P.3d 1196, 1239 (Kan. 2014).

255. Koski \& Reich, supra note 213 , at 608-10.
} 
equity in educational opportunity, each falling under the tenets of horizontal or vertical equity. ${ }^{256}$

The first horizontal equity method requires each school district receive the same level of funding. ${ }^{257}$ This method does not take into account that some students may need more resources in order to succeed, but is the easiest to administer. ${ }^{258}$ This method's focus is on equality in funding not equity, meaning that every school district would receive the same dollar amount from the state regardless of how much money is raised by the district's local property taxes. By uniformly raising the amount of state aid to districts, the gap in resources would remain the same. Except now the poor schools would be a bit less poor and the wealthy school districts would be a bit wealthier. Because of this, virtually no one supports the purely horizontal equity approach. ${ }^{259}$

The second horizontal equity method, sometimes called the " do no harm' principle," incorporates some aspects of vertical equity. ${ }^{260}$ The "do no harm" principle focuses on allocating funding so that the school system does not increase the inequity that exists between students when they walk through the school doors on the first day of class. ${ }^{261}$ Explained more plainly, this method would ensure that "after the completion of K12 education, children will occupy the same rank in the distribution of human and social capital as their parents."262 They leave school in exactly the same position as they entered it. Heard this way many of us would cringe, is it not the point that our children end up better off than ourselves?

Vertical equity provides us with two, more palatable options for defining equitable educational opportunity. One method aims to use educational opportunity to redress all background inequality, both social and physical. ${ }^{263}$ To achieve this, the state would have to provide enough funds to create, then carry out, an education system that compensates for physical disabilities, a student's bad home-life, mental disabilities, and anything else that could effect a child's education. More than just providing extra resources to help cope with these factors that impede educational performance, the state would have to ensure all children had

\footnotetext{
256. Id.

257. Id. at 608 .

258. Id

259. Id. at $608-09$.

260. Id. at 609 .

261. Id.

262. Id.

263. Id. at 610 .
} 
equity in educational outcomes as well. In light of all the considerations and variables involved, this method is overly aggressive and would require inordinate amounts of financial resources and human capital. It is of little surprise that this radical conception of vertical equity in educational opportunity is not widely supported.

A second method of utilizing vertical equity in educational opportunity is gaining ground with advocates and academics. ${ }^{264}$ This method seeks to use educational resources to redress "background social inequalities by directing additional resources to those students who are deemed needy." "265 The focus would be on redressing background social inequities ${ }^{266}$ such as language proficiency, income level, and access to early childhood education. ${ }^{267}$ This second vertical equity option can be seen in parts of Kansas's own school-finance system through the weighting factors included in the Quality Performance Act: "bilingual education students, vocational education students, at-risk students, ... and students who are transported." ${ }^{268}$ Acting to redress background social inequities has become the accepted conception of vertical equity, and in fact in school finance equity. And for obvious reasons, leaving our children as we found them is not the promise education makes. By utilizing this second method of achieving vertical equity in education funding, and thereby in educational opportunity, we can provide that non-native English speaker with the same quality education as her native English-speaking classmate.

\section{Equity in Kansas School-Finance Litigation: A Thoroughly Vertical Understanding}

Kansas courts should refuse horizontal equity as a means for understanding educational opportunity and utilize the advent of an equity test to embrace the tenets of vertical equity. Although Gannon's equity test does not use the term equity, its creation and application are colored by the court's background understanding of equity principles. In schoolfinance litigation to come, because there will be more, the courts should

264. See, e.g., id.; Tico A. Almeida, School Finance Litigation: Refocusing School Finance Litigation on At-Risk Children: Leandro v. State of North Carolina, 22 YALE L. \& POL'Y REV. 525, 526 (2004).

265. Koski \& Reich, supra note 213, at 610.

266. Disparities in wealth and power are often accompanied by discrimination or exclusion. alameda County Public Health Department, Life and Death From Unnatural Causes 25 (2008), http://www.acphd.org/media/144730/lduc-part2.pdf.

267. Koski \& Reich, supra note 213, at 610.

268. Unified Sch. Dist. No. 229 v. Kansas, 885 P.2d 1170, 1178 (Kan. 1994). 
consider whether schools have "substantially similar educational opportunity" through a vertical equity lens. Kansans have recognized the importance of equity in education since 1861, be it in funding, access to schools, or in the steadfast belief that separate can never be equal. ${ }^{269}$ It is time the courts apply a modern understanding of equity in school-finance litigation that mirrors the image of equity embodied in our constitution. Equity does not necessarily mean equality. But, the principles of fairness and justice that comprise equity demand more than ensuring the State provides every school district with an equal amount of additional funding. Equity requires more of the judiciary than the restricted view implied in Gannon.

1. How it was...

The Gannon court's road to announcing its new equity test was paved with notions of horizontal equity. Although the court did not explicitly consider what "substantially similar educational opportunity" would require, ${ }^{270}$ its language in arriving at the test reflects a "do no harm" understanding of educational opportunity. The "do no harm" principle provides that whatever the state spends on education should not worsen the inequities between low and high property-wealth districts, but does not ask the legislature to increase equity. ${ }^{271}$ This means that students will leave in relatively the same place they entered-no better, no worse. ${ }^{272}$ Certainly such a system would not be designed to meet Article VI's mandate that the legislature provide for educational improvement. $^{273}$

The "do no harm" rationale can be seen throughout the discussion leading up to Gannon's pronouncement of an equity test. The court repeatedly discussed the need for the legislature to avoid "increasing or exacerbating inequities" already inherent in the school funding system. ${ }^{274}$ In holding that the denial, or reduction, of state capital-outlay and supplemental-general aid violated Article VI, the court stressed that a satisfactory remedy could only be had if the legislature acts to reduce inequality. ${ }^{275}$ When the court focuses on decreasing inequity and not on

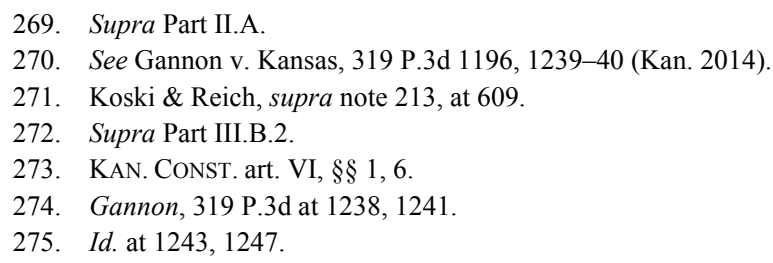


increasing equity, it is speaking in terms of the "do no harm" approach we all disapproved of earlier-whether it intends to or not. Advocates have the opportunity to ensure that the "do no harm" rhetoric in Gannon does not become law. To aid in this endeavor, they have support from Kansas school-finance litigation of old.

Throughout the Montoy litigation the court appeared to be concerned with the lack of vertical equity provided by the Quality Performance Act. At several stages of the litigation the district and supreme courts expressed concern with the Quality Performance Act's weighting factors. $^{276}$ The legislature had altered the weighting factors after the State's success in USD 229. ${ }^{277}$ Because the alterations were based on political compromise and not careful consideration of the actual cost of educating students, the supreme court found the new factor's violated Article VI. ${ }^{278}$ The Quality Performance Act's weighting factors served to provide increased funding to disadvantaged schools, a core tenet of vertical equity. ${ }^{279}$ The court's concern with the weighting factors' validity showed a concern with whether the school-funding system complied with notions of vertical equity, even if the court was not aware of it. However, as the litigation dragged on the court became less and less concerned with vertical equity as illustrated by Montoy III's pronouncement that the State owed \$285 million in additional school funding for the coming year. ${ }^{280}$ This focus merely on inputs while disregarding where the funds would go or what outcomes they would produce illustrates a shift back towards a horizontal equity approach.

2. How it ought to be...

In turning its back on adequacy issues and embracing a vertical equity approach to Gannon's equity test, the Kansas judiciary will be better able to assist the State in carrying out the promises of Article VI. Adequacy litigation comes from an admirable place, wishing to provide a quality education to all students. However, when the courts become a place for determining how much money makes an education adequate they infringe on the legislature's power. Not only does adequacy impose a separation of powers problem, it fails as a remedy. Courts cannot craft

\footnotetext{
276. STEGALL, supra note 109 , at $14,19$.

277. Id. at 13-14.

278. Montoy II, 120 P.3d 306, 310 (Kan. 2005).

279. Supra Part III.B.1.

280. STEGALL, supra note 109 , at 21.
} 
legislative policy; because of this the courts' only recourse in hearing adequacy challenges is to require additional funds. As evidenced in Kentucky and the nation as a whole, more money does not often make an education adequate. ${ }^{281}$ Adequacy fails to recognize that there are more things that go into crafting a quality education than money. In addition, adequacy litigation inevitably pits the judiciary against the legislature, a scenario from which no good can come. Montoy nearly led to a constitutional amendment limiting the powers of the judiciary, and Gannon has led the state right back to that terrifying cliff. $^{282}$

Although the judiciary is not sufficiently equipped to hear adequacy challenges, the courts are more than capable of determining whether a school-finance system violates principles of equity. The court need only occupy its usual role of considering a law placed before it and determining whether it passes a test that is derived from the text of the Kansas Constitution and its history. ${ }^{283}$ The Kansas Constitution has left it to the legislature to determine how and how much to fund schools. ${ }^{284}$ However, it is the duty of the judiciary to determine whether the legislature's funding scheme is equitable. To do this, Gannon developed an equity test: "School districts must have reasonably equal access to substantially similar educational opportunity through similar tax effort." ${ }^{285}$ The crux of this test, and the measure of its future usefulness, is how the courts approach defining "substantially similar educational opportunity." As seen in the language of Gannon and Montoy III, Kansas courts have followed the national trend of focusing on horizontal equity when considering school finance cases, though likely unwittingly. ${ }^{286}$ If courts decide to approach defining what "substantially similar educational opportunity" means from a horizontal equity perspective, they will be adopting the "do no harm" principle. Requiring the legislature to do no more than provide an education that leaves children in exactly the same position that they entered it in. ${ }^{287}$ This is not the Kansas understanding of equity and it does not aim to meet Article VI's requirement of attaining educational improvement.

\footnotetext{
281. Supra Part III.A.2.

282. Levy, supra note 57, at 1046; Push to Change Kansas Supreme Court, supra note 155.

283. See Van Sickle v. Shanahan, 511 P.2d 223, 235 (Kan. 1973) (stating that it is the court's job to apply laws in actual controversies).

284. Supra Part III.A.

285. Gannon v. Kansas, 319 P.3d 1196, 1239 (Kan. 2014) (emphasis added).

286. Supra Part III.C.1.

287. Supra Part III.B.2.
} 
Kansas has been striving to improve its education system since the first schoolhouse was built in 1851. But more than merely improving the education system as a whole, Kansans were concerned early on with providing additional resources to the disadvantaged. ${ }^{288}$ State funded special-education programs began in the early 1950s and in the 1970s Kansans realized the need for a curriculum that was more responsive to the individual needs of students. ${ }^{289}$ These accomplishments recognized the need to provide additional resources to disadvantaged Kansas students - the need for vertical equity. That inherent desire to do more through education than causing "no harm" is still present today. One need look no further than the inclusion of weighting factors in the Quality Performance Act. ${ }^{290}$ These weighting factors aim to provide additional resources to low property-wealth districts and disadvantaged students - the very definition of vertical equity.

If the judiciary's role is to ensure the constitution is being carried out and the constitution reflects the will of the people, ${ }^{291}$ then the judiciary should be informed by the tenets of vertical equity. By considering whether school districts have access to substantially similar educational opportunity through a vertical equity lens, the court will be carrying out the principles embodied in the Kansas Constitution. This would mean defining similar educational opportunity not to mean equal (or more equal) funding or similar curriculum, books, and buildings. Instead, the court should question whether the school-finance system is crafted to redress certain background social inequalities such as income-level, English language proficiency, and other factors that can impede educational opportunity and be redressed through access to additional resources.

Viewing the funding system in this way will not require the court to instruct the legislature on how much money to spend. Instead, the court would be looking at how the legislature distributes the moneys it sees fit to provide. We saw an example of this in Montoy II. There, the court required the legislature to base the Quality Performance Act's weighting factors on actual costs, not just political compromise. ${ }^{292}$ It is important to note that the court did not instruct the legislature on what the weighting

\footnotetext{
288. See supra Part II.A (discussing early education reforms in Kansas).

289. MARTINEZ \& SNIDER, supra note 29 , at 4,6 .

290. KAn. StAT. ANN. §§ 72-6411 to -6415a (2013), repealed by Act of Apr. 2, 2015, ch. 4, 2015 Kan. Laws S.B. 7.

291. See Gannon v. Kansas, 319 P.3d 1196, 1221 (Kan. 2014) ("We have long held that constitutions are the work of the people.").

292. Supra Part II.C.2.
} 
factors should be. Instead, the court found that the weighting factors were not distributing funds in accord with their vertical equity purpose and failed to do so because the legislature had not actually considered input and output equity in amending the law. ${ }^{293}$ The language of Gannon seemed to back track from Montoy II's view of vertical equity. ${ }^{294}$ However, the Gannon court was not specifically asked to look at the Quality Performance Act as a whole. ${ }^{295}$ Therefore, courts considering school-finance cases in the future are free to embrace a vertical equity approach to understanding educational opportunity and would be wise to do so.

The will of the people and Article VI of the Kansas Constitution are best served by approaching the definition of "substantially similar educational opportunity" from a vertical equity perspective. Although adopting this perspective may prove difficult at first, the difficulty will be small in comparison to the benefits it would afford Kansas students.

\section{CONCLUSION}

Kansas has a history of innovation, but it is far from unique in the realm of education litigation. School-finance litigation began in Kansas in the 1970s and proceeded to follow the three national waves with few variations. Unfortunately, the state's highest court recently followed the nation down the rabbit hole that is adequacy litigation. Once courts find adequacy justiciable there is no telling when the litigation will end. But there is still hope.

Kansas has the unique opportunity to utilize Gannon's newly minted equity test to improve the state of public education. The history of education reform in Kansas strongly supports viewing educational equity as requiring vertical equity. Courts can further the will of the people and the constitution, by defining "substantially similar educational opportunity" from a vertical equity perspective. In viewing Gannon's equity test through a vertical equity lens, Kansans can arm our children with that most powerful weapon-a quality education.

293. See Montoy II, 120 P.3d 306, 310 (Kan. 2005) (discussing weighting factors).

294. Supra Part III.C.1.

295. Gannon, 319 P.3d at 1204. 